\title{
TEACHER' SELF-EFFICACY: VERIFICATION OF THE PSYCHOMETRIC PROPERTIES OF QUESTIONNAIRE
}

\section{[VNIMANA PROFESIJNA ZDATNOST UCITELA - OVERENIE PSYCHOMETRICKÝCH VLASTNOSTI DOTAZNIKA OSTES]}

\author{
Katarina Kohutova
}

doi: 10.18355/PG.2018.7.2.5

\begin{abstract}
The submitted contribution concerns the verification of the psychometric properties of the Slovak version of the OSTES questionnaire on a sample of teachers of elementary and secondary schools (N 401). The Slovak translation of the original questionnaire was published in 2011 by author Gavora, who identified the factor structure of the questionnaire, identifying a one-factor solution. A year later, the questionnaire was re-validated that indicating a single and two-factor solution as appropriate. We decided to explore the psychometric properties of the OSTES questionnaire. Similarly to Gavora, we have come up with a one- and two-factor solution, but factorsaturation by some items is not consistent with Gavor's solution. In view of this, we propose to continue studying the factor structure of the Slovak translation of the OSTES questionnaire, thus increasing the likelihood of consensus on the factor solution of the given questionnaire and increasing its reliability and validity.
\end{abstract}

Key words

self-efficacy, OSTES questionnaire, psychometric characteristics, factor analysis

\begin{abstract}
Abstrakt
Predkladaný príspevok sa venuje overeniu psychometrických vlastností dotazníka OSTES na výskumnej vzorke učitel'ov základných a stredných škôl (N 401). Slovenský preklad pôvodného dotazníka bol uverejnený v roku 2011 autorom Gavorom, ktorý zist'oval faktorovú štruktúru dotazníka, pričom identifikoval jednofaktorové riešenie. O rok neskôr dotazník revalidoval, pričom ako vhodné, uvádza jedno- i dvojfaktorové riešenie. Rozhodli sme sa preskúmat' psychometrické vlastnosti prekladu dotazníka OSTES. Podobne ako autor Gavora, sme dospeli k jedno- i dvojfaktorovému riešeniu, avšak faktorové sýtenia niektorými položkami nie sú v zhode s riešením autora Gavoru. S ohl'adom na to navrhujeme, aby sa pokračovalo vo výskume faktorovej štruktúry slovenského prekladu dotazníka OSTES, čím sa zvýši pravdepodobnost' konsenzu o faktorovom riešení daného dotazníka a zvýši sa jeho reliabilita a validita.
\end{abstract}

\section{Kl'účové slová}

vnímaná profesijná zdatnost' učitel'a, self-efficacy, dotazník OSTES, psychometrické charakteristiky, faktorová analýza 


\section{Teoretické východiská}

Pedagogická činnost' učitel'a je determinovaná mnohými faktormi, napr. jeho odbornými vedomost’ami, schopnost’ami, motiváciou, ašpiráciami a pod., ale ako uvádza Gavora (2008) i predstavou, akú o sebe učitel' má, tzn. ako vníma (posudzuje, hodnotí) sám seba ako učitel'a. Táto predstava je významným faktorom, ktorý (ak je pozitívna) môže podporovat' a facilitovat' pôsobenie učitel'a $\mathrm{v}$ triede, resp. ho brzdit' (ak je negatívna). Vnímanú profesijnú zdatnost' učitel'a (jeho učitel'ské self-efficacy) môžeme chápat' ako subjektívne hodnotenie potenciality vykonávat' určitú činnost'. Jedná sa o presvedčenie o vlastných schopnostiach a možnostiach realizácie týchto schopností za daných podmienok (Gavora, 2008). Je to hl'adisko vel'mi odlišné od teoretických modelov učitel'ských kompetencií i od objektívne hodnotených vlastností učitel'a. Jedná sa totiž o subjektívny pohl'ad učitel'a na seba (Gavora, 2012). Ide o ,presvedčenie učitel'a o svojich schopnostiach, ktoré ho predurčujú k úspechom v plnení edukačných úloh“ (Majerciková, Gavora, 2013: 128). Táto teória zdôrazňuje rolu presvedčenia o sebe samom, ktorá determinuje subjektívne hodnotenie toho o čom je jedinec presvedčený, že ešte zvládne a čo už nie. Ako uvádzajú autorky Nikodemova, Fenyvesiova a Tirpakova (2017) výskum self-efficacy potvrdil tézu, že úsudok človeka o subjektívnej, osobne vnímanej zdatnosti v konkrétnej činnosti je dobrým prediktorom výkonu v danej činnosti.

Teoretické pozadie merania konštruktu self-efficacy vychádza z Rotterovej teórie sociálneho učenia (locus of control) a Bandurovej sociálno-kognitívnej teórie (self-efficacy). Self-efficacy učitel'a sa skúma už viac ako 30 rokov (Gavora, 2012). Počiatky merania konštruktu učitel'ovho self-efficacy sa spájajú s vedcami americkej spoločnosti Rand, ktorí vychádzali zo spomínanej Rotterovej teórie sociálneho učenia. Títo výskumníci merali selfefficacy dvoma položkami na 5-stupňovej likertovej škále. V snahe zvýšit' validitu a reliabilitu dvojpoložkovej verzie následne vyvinuli autori Gibson a Dembo 30-položkový dotazník (Teacher Efficacy Scale - TES), ktorý prináša dva faktory (učitel'ovo presvedčenie o svojich schopnostiach a potencionality vyučovania vnímané učitel'om), pričom teoreticky vychádzali z Bandurovej sociálno-kognitívnej teórie. Neskoršie výskumy však ukázali rôzne nezrovnalosti vo faktorovej štruktúre dotazníka, napr. niektoré položky sýtili oba faktory, alebo niektoré položky nemali dostatočné faktorové zat’aženie, príp. bola otázna dvojfaktorová štruktúra dotazníka (Woolfolk Hoy, 2000). Uprostred nejasností o najvhodnejšom spôsobe merania self-efficacy vytvoril Bandura vlastný nástroj - Teacher Self Efficacy Scale. Ako upozorňuje Gavora (2008) tento dotazník nemal širšie uplatnenie, ale rešpektoval požiadavky jeho autora, že dotazník by mal reflektovat' situačné hl'adisko vnímanej zdatnosti (napr. tým, že v koreni škály bude výraz „I can“", „Som schopný“, „,viem to urobit"“), položky by mali opisovat' určitú činnost', na vykonanie ktorej musí učitel' vyvinút' určitú námahu, úsilie (Gavora, 2009).

Výskumníci z Ohijskej štátnej univerzity sa snažili vymedzit' svoju pozíciu medzi globálnym pohl'adom na vnímanú zdatnost' učitel'a (ako to bolo v dotazníku TES) a špecifickým pohl'adom ako ho odporúča Bandura (avšak 
s pohl'adom dost' všeobecným, aby odrážal rôzne roviny vyučovania a mohol sa používat' naprieč rôznymi predmetmi). Výskumný nástroj, ktorý vyvinuli sa nazýva The Ohio State Teacher Efficacy Scale (OSTES) (Gavora, 2011). Autormi sú Tschannen-Moran a Woolfolk Ho (2001). V prvom kroku vývoja nástroja vychádzali z dotazníka autora Banduru a zostavili pracovnú skupinu 9 odborníkov (výskumníci, doktorandi, učitelia), ktorí vyberali položky z Bandurovej škály, pričom každý z účastníkov pridal 8 až 10 nových položiek, ktoré neboli v dotazníku Banduru, ale podl'a nich reprezentovali zdatnost' učitel'a. Týmto spôsobom bolo vytvorených okolo 100 položiek. Následne pracovná skupina o jednotlivých položkách diskutovala a zhodla sa na 52 položkách. Nový merací nástroj bol následne testovaný v troch štúdiách, pričom konečná verzia mala 24 položiek a skrátená verzia 12 položiek. Faktorovou analýzou boli extrahované tri faktory, pričom dlhá forma vysvetl'ovala $54 \%$ variancie a krátka forma $65 \%$ variancie. Prvý faktor sa nazýval zdatnost' motivovat' žiakov, druhý zdatnost' používat' vyučovacie stratégie a tretí zdatnost' manažovat' triedu. Autori zároveň uvažovali o vhodnosti jednofaktorového riešenia, ktoré pri dlhej verzii vysvetl'ovalo $75 \%$ variancie a pri krátkej $68 \%$ variancie.

Slovenskú verziu dotazníka OSTES validoval Gavora (2011) na výskumnej vzorke učitel’ov základných škôl. Prvým krokom bol preklad dotazníka, pričom zvolil tzv. adekvátny preklad. Následne stanovil jeho faktorovú štruktúru. Faktorovú analýzu realizoval prostredníctvom metódy hlavných komponentov a metódou hlavnej osi a rotáciou Varimax. Kaiserovo číslo ukazovalo na možnost' uvažovat' o štyroch faktoroch, scree test udával jeden faktor. Citovaný autor overil všetky ponúkané eventuality s tým, že riešenia s viacerými faktormi nepriniesli dobré výsledky. Mnohé položky zapadli do viacerých faktorov, preto sa rozhodol pre jeden faktor. Slovenská verzia OSTES je unidimenziálna, pričom toto riešenie vysvetlilo $44,6 \%$ variancie, vnútorná konzistencia testu bola adekvátna $(0,94)$. Výskumný súbor tvorilo 158 učitel'ov základných škôl. Škály dotazníka boli konštruované tak, že čím je vyššie skóre, tým je vnímaná profesijná zdatnost' lepšia. Dotazník obsahoval 9-bodové škály, ktorých stredová poloha bola 5. Aritmetický priemer výskumného súboru bol 7,15 (SD 0,93), čo vysoko presiahlo stredovú polohu. To znamená, že učitelia majú vysokú profesijnú zdatnost' a na väčšinu položiek odpovedali v priemere odpoved'ou „,dost““. Štatisticky významne sa respondenti s kratšou (do 5 rokov) a dlhšou (nad 5 rokov) nelíšili, rovnako sa nelíšili ani muži a ženy, či učitelia na 1 . a 2 stupni. Spomínaná validizácia priniesla jeden faktor i otázku, či je toto faktorové riešenie najlepšie. Následne citovaný autor v roku 2012 re-validoval spomínaný výskumný nástroj na výskumnej vzorke 182 učitel'ov základných škôl (z toho $79,6 \%$ žien s praxou nad 5 rokov). V rámci re-validizácie sa ukázal ako najlepší výsledok s dvomi faktormi, pričom citovaný autor eliminoval 9 položiek, ktoré mali faktorové zát'aže v oboch faktoroch. V tejto podobe zostalo v dotazníku 15 položiek.

Ciel'om predkladaného článku je overit' faktorovú štruktúru dotazníka OSTES osobitne pre učitel'ov základných a stredných škôl.

\section{Výskumná vzorka}


Výskumnú vzorku tvorilo 401 učitel'ov, z toho 202 učilo na základných školách a 199 na stredných školách. Prevládalo ženské pohlavie (N 332) v porovnaní s mužským (N 69). Priemerný vek výskumného súboru bol 45,2 rokov (SD 10,40 rokov). Priemerná dížka praxe bola 19,2 rokov (SD 11,42 rokov). Zastúpenie mali všetky kraje na Slovensku.

Pracovali sme so 6 -bodovou škálou $(1=$ vôbec nič, $6=$ vel'mi vel'a $)$, na rozdiel od autoriek dotazníka Gibsonovej a Dembu (1984) i autora Gavoru (2011, 2012), ktorí používali 9-bodovú škálu. Podl'a nášho názoru, 6-bodová škála bola dostačujúca pre zachytenie variability odpovedí učitel’ov a domnievame sa, že príliš široká škála (7 bodov a viac) mätie respondentov.

\section{Overenie faktorovej štruktúry dotazníka OSTES}

Dáta sme podrobili faktorovej analýze s ciel'om zistit' faktorovú štruktúru dotazníka. Zaujímalo nás, či sa nám podarí potvrdit' existenciu troch faktorov, ktoré identifikovali autorky dotazníka Tschannen-Moran a Woolfolk Ho (2001), alebo existenciu dvoch, príp. jedného faktora, ktoré identifikoval v slovenskej adaptácii dotazníka autor Gavora $(2011,2012)$.

Používali sme metódu hlavných komponentov a rotáciu Varimax. Sutinový graf i Kaiserovo pravidlo poukazovali na riešenie s dvoma faktormi (ZŠ i SŠ).

Výsledok KMO testu bol 0,958 (ZŠ) a 0,953 (SŠ) a výsledok Barlett's Sphericity testu bol štatisticky signifikantný (ZŠ: $\chi^{2}=4435,215, p=0,000$; SŠ $: \chi^{2} 3605,638 \mathrm{p}=0,000$ ).

Dva faktory boli vhodným riešením ako pre učitel'ov na ZŠ i SŠ - vid' tab. č. 1. Položky, ktoré jednotlivé faktory sýtili boli pre obe skupiny učitel'ov identické, až na tri položky ( $\mathrm{v}$ tabul'ke vyznačené tučným). Jedná sa o položku z prvého faktora ,,ked” žiaci vôbec nerozumejú učivu“, ktorá sýti prvý faktor len u učitel'ov ZŠ, z druhého faktora sa jedná o položky: „pre rodiny, aby ich deti prospievali $v$ škole“ a „aby žiaci pochopili, aké správanie od nich očakávate", ktoré sýtili druhý faktor, znova len u učitel’ov ZŠ.

Riešenie $\mathrm{s}$ dvomi faktormi sa $\mathrm{z}$ hl'adiska interpretovatel'nosti zdá byt' najlepšie, avšak museli sme eliminovat' 6 položiek, ktoré sýtili oba faktory (v tabul'ke č. 1 sú uvedené na konci, riadky sú podfarbené sivou). 


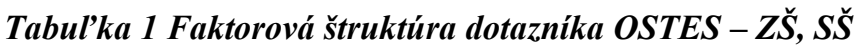

\begin{tabular}{|c|c|c|c|c|}
\hline \multirow{2}{*}{ Čo ste schopný/á urobit’... } & \multicolumn{2}{|c|}{$\mathbf{S S \check { S }}$} & \multicolumn{2}{|c|}{$\mathbf{Z S ̌ S}$} \\
\hline & 1 & 2 & 1 & 2 \\
\hline na rozvíjanie tvorivosti žiakov? & ,253 & ,757 & ,359 & ,761 \\
\hline ked'vám žiaci dávajú t'ažké otázky? &, 252 & ,756 & ,363 &, 740 \\
\hline aby žiaci lepšie pochopili učivo? & ,367 & ,754 & ,435 & ,788 \\
\hline $\begin{array}{l}\text { aby ste zaviedli inovácie do vášho } \\
\text { vyučovania? }\end{array}$ & ,208 & ,769 & ,444 &, 727 \\
\hline $\begin{array}{l}\text { aby ste prispôsobili náročnost’ učiva } \\
\text { schopnostiam žiakov? }\end{array}$ & ,310 & ,687 & ,387 & ,767 \\
\hline $\begin{array}{l}\text { aby ste použivali pestré možnosti } \\
\text { preverovania vedomostí a zručností? }\end{array}$ & ,291 & ,723 & ,352 & ,782 \\
\hline $\begin{array}{l}\text { aby ste podporovali rozvoj } \\
\text { talentovaných žiakov? }\end{array}$ &, 255 & ,705 & ,390 & ,762 \\
\hline $\begin{array}{l}\text { aby ste formulovali žiakom } \\
\text { primerané otázky? }\end{array}$ &, 193 &, 814 & ,292 &, 857 \\
\hline ked' žiaci vôbec nerozumejú učivu? &, 549 &, 587 &, 483 & ,705 \\
\hline s vel'mi problémovými žiakmi? & ,730 & 1,165 & ,686 & 2,219 \\
\hline $\begin{array}{l}\text { na zvýšenie motivácie žiakov, ktorých } \\
\text { vyučovanie nezaujíma? }\end{array}$ & ,693 &, 381 &, 653 & ,365 \\
\hline voči drzým žiakom? &, 872 & 151 &, 783 & ,328 \\
\hline aby ste zvládli vyrušujúcich žiakov? & ,797 & ,400 & ,748 & ,487 \\
\hline $\begin{array}{l}\text { aby žiaci dodržiavali školský } \\
\text { poriadok? }\end{array}$ &, 761 & ,308 &, 721 & ,451 \\
\hline $\begin{array}{l}\text { aby ste zabránili vyrušovaniu } \\
\text { žiakov? }\end{array}$ &, 810 & ,262 & ,693 & ,368 \\
\hline $\begin{array}{l}\text { aby ste eliminovali jednotlivcov, } \\
\text { ktorí sú schopní rozbit' celú hodinu? }\end{array}$ & ,816 & ,237 &, 735 & ,387 \\
\hline $\begin{array}{l}\text { pre rodiny, aby ich deti prospievali v } \\
\text { škole? }\end{array}$ & ,496 & ,357 &, 701 & ,303 \\
\hline $\begin{array}{l}\text { aby žiaci pochopili, aké správanie } \\
\text { od nich očakávate? }\end{array}$ &, 568 &, 566 & ,707 & ,466 \\
\hline $\begin{array}{l}\text { aby ste v triede zaviedli dobrý systém } \\
\text { riadenia? }\end{array}$ &, 627 &, 576 &, 541 & ,676 \\
\hline $\begin{array}{l}\text { aby ste presvedčili žiakov, že majú } \\
\text { naviac? }\end{array}$ & ,495 & ,624 & ,606 &, 518 \\
\hline $\begin{array}{l}\text { aby ste prehĺbili vaše poznanie, } \\
\text { prečo žiak neprospieva? }\end{array}$ &, 552 &, 522 &, 548 & ,622 \\
\hline $\begin{array}{l}\text { aby ste naučil(a) žiakov kriticky } \\
\text { mysliet? }\end{array}$ &, 545 & ,467 &, 578 & ,456 \\
\hline aby si vaši žiaci vážili vzdelávanie? &, 655 & ,432 &, 681 & ,483 \\
\hline $\begin{array}{l}\text { aby rutinné činnosti na vyučovaní } \\
\text { prebiehali hladko? }\end{array}$ &, 538 &, 553 & ,479 & ,678 \\
\hline
\end{tabular}




\section{Faktorová štruktúra dotazníka OSTES pre učitel'ov ZŠ}

Finálny obraz faktorovej štruktúry, po vynechaní problematických položiek, pre učitel'ov ZŠ je uvedený v tab. č. 2. Jedná sa o dvojfaktorovú štruktúru, pričom každý faktor je sýtený 9 položkami. Identifikované faktory vysvetl'ujú $70,70 \%$ variancie, čo je pri dvoch faktoroch vel'mi dobrý výsledok. Reliabilita položiek prvého faktora je $\alpha=0,955$, a druhého $\alpha=0,936$, na základe čoho môžeme konštatovat', že vnútorná konzistencia faktorov dotazníka je výborná.

Tabul'ka 2 Finálna verzia faktorovej štruktúry učitel'ov ZŠ

\begin{tabular}{|c|c|c|}
\hline \multirow{2}{*}{ Čo ste schopný/á urobit’... } & \multicolumn{2}{|c|}{$\mathbf{Z} \check{\mathbf{S}}$} \\
\hline & 1 & 2 \\
\hline aby ste formulovali žiakom primerané otázky? & ,857 & ,300 \\
\hline $\begin{array}{l}\text { aby ste použivali pestré možnosti preverovania } \\
\text { vedomostí a zručností? }\end{array}$ & ,784 & ,366 \\
\hline aby žiaci lepšie pochopili učivo? & ,784 & ,447 \\
\hline na rozvíjanie tvorivosti žiakov? & ,779 & ,342 \\
\hline $\begin{array}{l}\text { aby ste podporovali rozvoj talentovaných } \\
\text { žiakov? }\end{array}$ & ,768 & ,389 \\
\hline $\begin{array}{l}\text { aby ste prispôsobili náročnost’ učiva } \\
\text { schopnostiam žiakov? }\end{array}$ & ,765 & ,397 \\
\hline ked'vám žiaci dávajú t’ažké otázky? & ,735 & ,359 \\
\hline aby ste zaviedli inovácie do vášho vyučovania? & ,730 & ,449 \\
\hline ked'žiaci vôbec nerozumejú učivu? &, 705 &, 493 \\
\hline voči drzým žiakom? & ב,319 & ,807 \\
\hline aby ste zvládli vyrušujúcich žiakov? & ,462 & ,772 \\
\hline $\begin{array}{l}\text { aby ste eliminovali jednotlivcov, ktorí sú } \\
\text { schopni rozbit' celú hodinu? }\end{array}$ & ,376 &, 758 \\
\hline aby žiaci dodržiavali školský poriadok? & ,434 & ,734 \\
\hline aby ste zabránili vyrušovaniu žiakov? & ,358 & ,707 \\
\hline $\begin{array}{l}\text { aby žiaci pochopili, aké správanie od nich } \\
\text { očakávate? }\end{array}$ & ,460 & ,707 \\
\hline pre rodiny, aby ich deti prospievali v škole? & ,311 &, 695 \\
\hline$s$ vel’mi problémovými žiakmi? & ,244 & ,664 \\
\hline $\begin{array}{l}\text { na zvýšenie motivácie žiakov, ktorých } \\
\text { vyučovanie nezaujíma? }\end{array}$ & ,389 & ,639 \\
\hline
\end{tabular}

\section{Faktorová štruktúra dotazníka OSTES pre učitel'ov SŠ}

Finálny obraz faktorovej analýzy pre učitel'ov SŠ je uvedený v tab. č. 3. Jedná sa o dvojfaktorovú štruktúru, pričom prvý faktor je sýtený 8 položkami a druhý faktor je sýtený 7 položkami. Identifikované faktory vysvetl'ujú $67,50 \%$ variancie. Vnútorná konzistencia položiek prvého faktora je $\alpha=$ 0,920, a druhého $\alpha=0,921$, na základe čoho môžeme konštatovat', že reliabilita faktorov dotazníka je výborná. 
Tabul'ka 3 Finálna verzia faktorovej štruktúry učitel'ov SŠ

\begin{tabular}{|c|c|c|}
\hline \multirow{2}{*}{ Čo ste schopný/á urobit’... } & \multicolumn{2}{|c|}{ S Š́ } \\
\hline & 1 & 2 \\
\hline aby ste formulovali žiakom primerané otázky? &, 815 & 202 \\
\hline aby ste zaviedli inovácie do vášho vyučovania? & ,783 & ,198 \\
\hline na rozvijanie tvorivosti žiakov? & ,765 & 230 \\
\hline aby žiaci lepšie pochopili učivo? & ,759 & ,361 \\
\hline ked'vám žiaci dávajú t’ažké otázky? & ,753 & 276 \\
\hline aby ste podporovali rozvoj talentovaných žiakov? & ,737 & 244 \\
\hline $\begin{array}{l}\text { aby ste použivali pestré možnosti preverovania } \\
\text { vedomosti a zručností? }\end{array}$ & ,727 & ,298 \\
\hline $\begin{array}{l}\text { aby ste prispôsobili náročnost' učiva } \\
\text { schopnostiam žiakov? }\end{array}$ & ,693 & ,325 \\
\hline voči drzým žiakom? & ,172 & $\overline{8,872}$ \\
\hline aby ste zabránili vyrušovaniu žiakov? & ,264 &, 831 \\
\hline $\begin{array}{l}\text { aby ste eliminovali jednotlivcov, ktorí sú schopni } \\
\text { rozbit' celú hodinu? }\end{array}$ & ,277 &, 821 \\
\hline aby ste zvládli vyrušujúcich žiakov? & ,415 & ,788 \\
\hline aby žiaci dodržiavali školský poriadok? & ,329 &, 752 \\
\hline s vel'mi problémovými žiakmi? & ,189 &, 742 \\
\hline $\begin{array}{l}\text { na zvýšenie motivácie žiakov, ktorých vyučovanie } \\
\text { nezaujíma? }\end{array}$ & ,394 & ,682 \\
\hline
\end{tabular}

Deskriptívna a korelačná analýza faktorov

Prvý faktor sa nazýva Zdatnost' používat' vyučovacie stratégie a týka sa zdatnosti učitel'a používat' postupy a metódy vo vyučovaní. Druhý faktor sa nazýva Zdatnost' manažovat' triedu a týka sa zdatnosti učitel'a regulovat' správanie v triede.

Ako vyplýva z priemerných hodnôt, subjektívne hodnotenie zdatnosti učitel'ov prekračuje v oboch faktoroch hypotetický stred škály, ktorý je vyjadrený hodnotou 3,5. To naznačuje, že učitelia pôsobiaci ako na ZŠ, tak SŠ sú subjektívne presvedčení o relatívne vysokej hodnote vlastnej zdatnosti (vyššie sa hodnotia v zdatnosti používat' vyučovacie stratégie v porovnaní so zdatnost'ou manažovat' triedu).

Pri porovnaní priemerných hodnôt učitel'ov pôsobiacich na ZŠ a SŠ v jednotlivých faktoroch môžeme vidiet' len minimálne rozdiely, to znamená, že priemerná vnímaná self-efficacy je u učitel'ov vel'mi podobná.

Realizovali sme i korelačnú analýzu medzi faktorom zdatnost' manažovat' triedu a zdatnost' používat' vyučovacie stratégie. Korelačná analýza preukázala vysokú súvislost' medzi faktormi, u učitel'ov ZŠ ( $\left.\mathrm{r}=0,805^{* *}\right)$, u učitel'ov SS̆ ( $\left.r=0,647^{* *}\right)$, čo znamená, že identifikované faktory nie sú navzájom nezávislé.

V grafoch 1 až 4 sú vizualizované histogramy identifikovaných faktorov. 
Tabul'ka 4 Deskriptívna charakteristika faktorov: zdatnost' manažovat' triedu a zdatnost' používat' vyučovacie stratégie

\begin{tabular}{|c|c|c|c|c|}
\hline & $\begin{array}{l}\text { Zdatnost' } \\
\text { manažovat' } \\
\text { triedu - Ž́ }\end{array}$ & $\begin{array}{c}\text { Zdatnost' } \\
\text { manažovat' } \\
\text { triedu - SŠ }\end{array}$ & $\begin{array}{c}\text { Zdatnost' } \\
\text { používat' } \\
\text { vyučovacie } \\
\text { stratégie - } \\
\text { ZS }\end{array}$ & $\begin{array}{l}\text { Zdatnost' } \\
\text { používat' } \\
\text { vyučovacie } \\
\text { stratégie - } \\
\text { SS }\end{array}$ \\
\hline $\mathrm{N}$ & 202 & 200 & 202 & 200 \\
\hline Priemer & 4,09 & 4,05 & 4,66 & 4,68 \\
\hline Medián & 4,24 & 4,29 & 4,89 & 4,88 \\
\hline Modus & 4 & 5 & 5 & 5 \\
\hline $\begin{array}{l}\text { Štandardná } \\
\text { odchýlka }\end{array}$ & 1,003 & 1,099 & ,967 &, 875 \\
\hline Šikmost' & $-0,464$ & $-0,540$ & $-1,022$ & $-0,839$ \\
\hline Strmost' & $-0,554$ & $-0,296$ & 0,490 & 0,532 \\
\hline Minimum & 1 & 1 & 2 & 2 \\
\hline Maximum & 6 & 6 & 6 & 6 \\
\hline
\end{tabular}




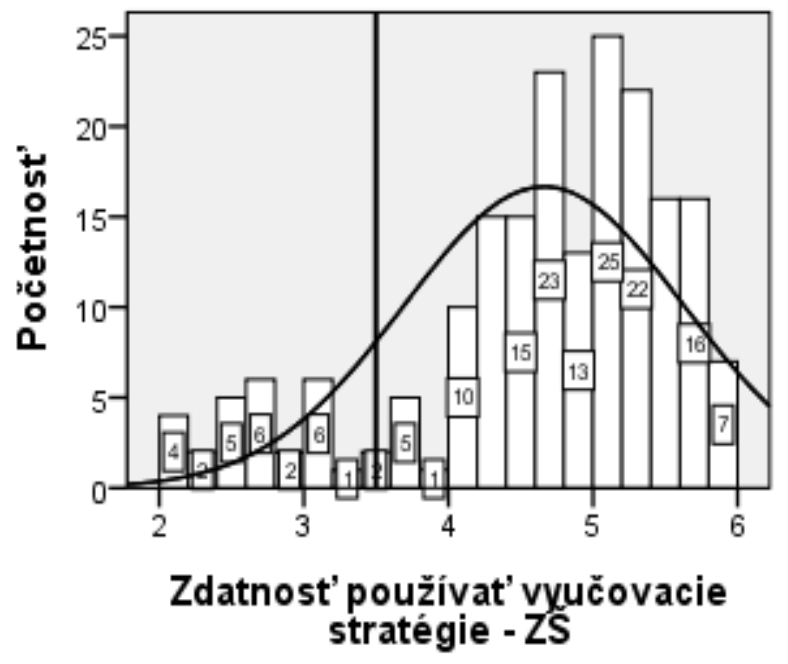

Graf 1 Zdatnost' používat' vyuč. stratégie - ŽS

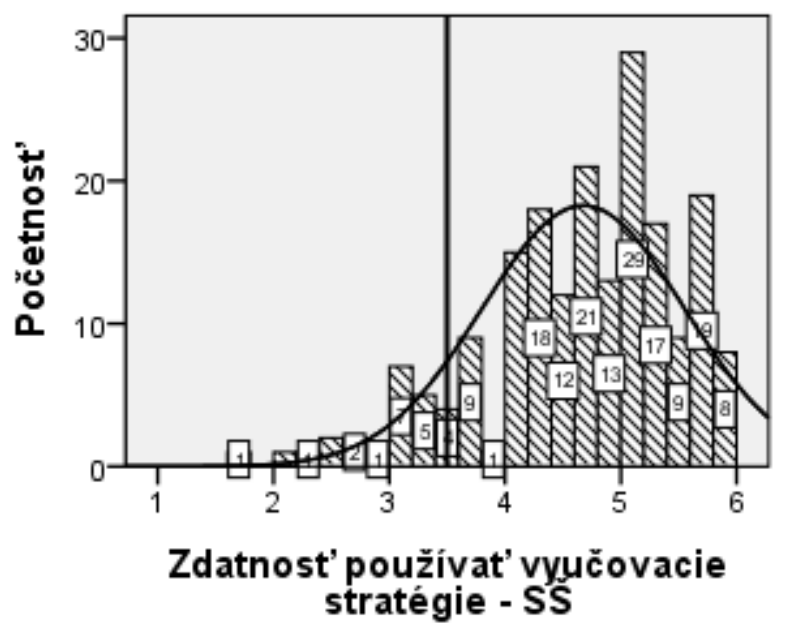

Graf 2 Zdatnost' používat' vyuč. stratégie - SS̆ 


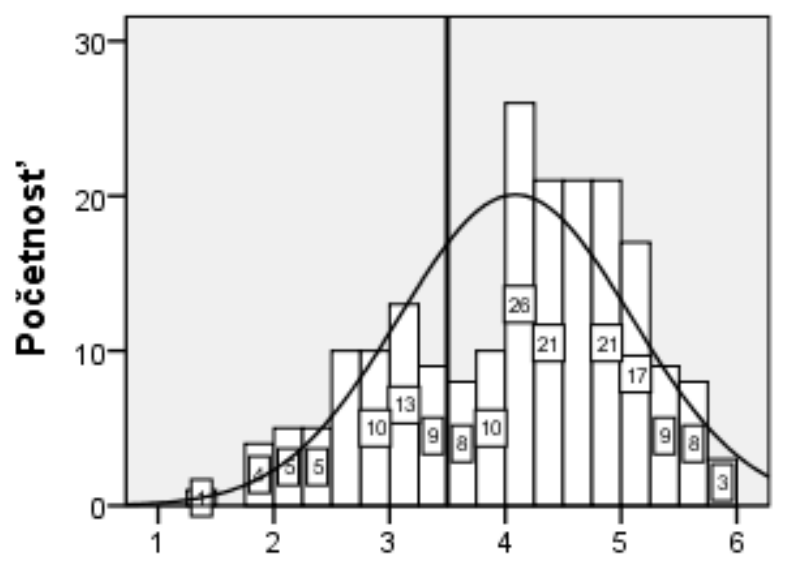

\section{Zdatnost' manažovat' triedu - ZŠ}

Graf 3 Zdatnost' manažovat' triedu $-Z \check{S}$

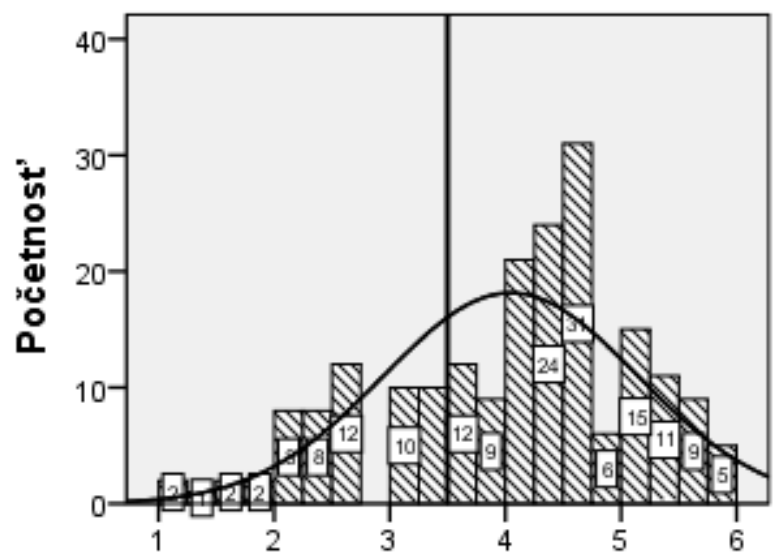

\section{Zdatnost' manažovat' triedu - SŠ}

Graf 4 Zdatnost' manažovat' triedu - Š̆

\section{Diskusia}

Autor Gavora (2012) revalidoval dotazník OSTES na výskumnej vzorke učitel'ov základných škôl, preto sa v nasledujúcom texte venujeme komparácii faktorovej štruktúry, ktorú sme identifikovali u učitel'ov základných škôl. Citovaný autor v re-validizácii identifikoval dva faktory, ktoré sýtilo 15 položiek. V našom prípade sa jednalo o 18 položiek.

Diferenciácie sme zaznamenali pri položke ,aby ste prispôsobili náročnost’ učiva schopnostiam žiakov", ktorá v prípade autora Gavoru z faktora 1 (Zdatnost' používat' vyučovacie stratégie) vypadla. Naopak, z našej faktorovej štruktúry vypadli položky: ,aby ste naučil/a žiakov kriticky mysliet"“ a ,aby rutinné činnosti na vyučovaní prebiehali hladko“. Posledné spomínané položky boli vylúčené, pretože sýtili oba faktory. Položka ,aby 
ste naučil/a žiakov kriticky mysliet"“ mala i v prípade citovaného autora, nízke (avšak prijatel'né) faktorové sýtenie $(0,417)$.

V rámci druhého faktora (Zdatnost' manažovat' triedu) sme diferenciácie zaznamenali pri položkách: „, aby žiaci dodržiavali školský poriadok“, ,aby žiaci pochopili, aké správanie od nich očakávate“, „pre rodiny, aby ich deti prospievali v škole“ a „na zvýšenie motivácie žiakov, ktorých vyučovanie nezaujíma“, ktoré v prípade výsledného obrazu faktorovej analýzy citovaného autora boli vylúčené. V našom prípade mali vysoké faktorové sýtenie, teda primerane zapadali do štruktúry druhého faktora. Vo faktorovej štruktúre zvyšných položiek sme nezaznamenali s citovaným autorom žiadne diferenciácie.

Rozdiel medzi nami identifikovanou faktorovou štruktúrou a faktorovou štruktúrou autora Gavoru je i v počte položiek. V našom prípade sýtilo oba faktory ideálne rovnaký počet deviatich položiek.

Rovnako ako v prípade autora Gavoru (2012) i v našom prípade, úplne vypadla tretia dimenzia ,Zdatnost' motivovat' žiakov“, ktorú identifikovali autori dotazníka Tschannen-Moran a Woolfolk Ho (2001). Z tohto faktora sa niektoré položky pridružili k dvom identifikovaným faktorom, napr. položky „,na rozvijanie tvorivosti žiakov" či ,aby ste podporovali tvorivost' žiakov “ pripadla k prvému faktoru (Zdatnost' používat' vyučovacie stratégie), čo slovenskí učitelia považujú skôr za zdatnost' súvisiacu s vyučovacími stratégiami ako so zdatnost'ou motivovat' žiakov. Položka „na zvýšenie motivácie žiakov, ktorých vyučovanie nezaujíma" pripadla do druhého faktora, teda zdatnost' manažovat' triedu. Zdá sa, že slovenskí učitelia považujú žiakov, ktorých vyučovanie nezaujíma vistom ohl'ade za problematických (spadajú k položkám ako napr. „čo ste schopný/á urobit' $s$ vel'mi problémovými žiakmi“).

Čo sa týka porovnania faktorovej štruktúry u učitel’ov základných a u učitel'ov stredných škôl, dospeli sme k diferenciácii v troch položkách. Položky, čo ste schopný/á urobit' ,,ked’ žiaci vôbec nerozumejú učivu“, „,pre rodiny, aby ich deti prospievali v škole“ a ,aby žiaci pochopili, aké správanie od nich očakávate" spadala len ku faktorom u učitel’ov základných škôl. Z toho je možné usudzovat, že pre učitel'ov základných škôl tú tieto položky dôležitým komponentom zdatnosti či už manažovat' triedu, alebo používat' vyučovacie stratégie, na rozdiel od učitel'ov stredných škôl. Je to pochopitel'né, pretože stredoškolský učitel' má menší dosah ako na rodinu žiaka, a z didaktického hl'adiska preberá so žiakmi abstraktnejšie a zložitejšie témy v porovnaní s učitel'om základnej školy, čo sa mohlo odrazit' v spomínaných rozdieloch. Faktorové sýtenie ostatných položiek bolo identické u učitel'ov základných i stredných škôl.

\section{Záver}

Faktorová analýza preukázala existenciu dvoch faktorov self-efficacy (zdatnosti učitel'ov), ktoré charakterizujú jej didaktickú a manažérsku stránku. Spočívajú v zdatnosti učitel'a vzdelávat' žiakov a zvládat' disciplínu $\mathrm{v}$ triede. V porovnaní s pôvodnou faktorovou štruktúrou dotazníka autorov Tschannen-Moran a Woolfolk Ho (2001) vypadol tretí faktor zdatnost' 
motivovat' triedu, čo môže byt' determinované odlišným edukačným prostredím, skladbou žiakov, ale i prekladom škály.

Súhrnne môžeme konštatovat', že najvhodnejším riešením bolo dvojfaktorové riešenie (pre učitel'ov ZŠ i SŠ), avšak u učitel'ov ZŠ sme museli eliminovat' 6 položiek, u učitel'ov SŠ 8 položiek, pretože sýtili oba faktory. Položky sýtiace identifikované dva faktory boli u učitel'ov ZŠ a SŠ identické, až na tri položky. Okrem dvojfaktorového riešenia navrhujeme používat' škálu OSTES i ako unidimenzionálnu, tak ako to navrhujú autori dotazníka OSTES Tschannen-Moran a Woolfolk Ho (2001) i autor Gavora (2011). Korelácie medzi faktormi sú vysoké, to znamená, že faktory na sebe nie sú nezávislé, preto sa nám javí ako prijatel’ná i unidimenzionálna alternatíva dotazníka.

Validizácia dotazníka je náročný proces, ktorý často prináša rozporuplné a nejednoznačné výsledky, čo potvrdila i naša štúdia. Pri používaní uvedeného dotazníka na výskumné účely odporúčame overovat' jeho faktorovú štruktúru, vnútornú konzistenciu i medzifaktorové korelácie, čo pomôže $\mathrm{k}$ zjednoteniu tohto užitočného nástroja a $\mathrm{k}$ zvýšeniu jeho spol'ahlivosti vo výskume.

Článok je priebežným výsledkom riešenia vedecko-výskumnej úlohy KEGA 007KU-4/2017 „Prejavy devalvačného správania žiakov voči učitel’om“.

\section{Bibliographic references}

GAVORA, P. 2008. Profesijna zdatnost vnimana ucitelom. Adaptacia vyskumneho nastroja. In Pedagogicka revue, roc. 50, c. 3 - 4 .

GAVORA, P. 2011. Zistovanie profesijnej zdatnosti ucitela pomocou dotaznika OSTES. In Pedagogika.sk, roc. 2, c. 2, s. $88-107$.

GAVORA, P. 2012. Rozvoj vnimanej zdatnosti (self-efficacy) studentov ucitelstva: moznosti zlepsenia ucitelskeho vzdelavania In Aula, roc. 20, c. 1, s. $62-77$.

MAJERCIKOVA, J., GAVORA, P. 2013. Vnimaná zdatnost (self-efficacy) ucitela spolupracovat $\mathrm{s}$ rodicmi: konstrukcia vyskumneho nastroja. In Metodologicka studie, c. 2, s. 128 - 146.

NIKODEMOVA, V. - FENYVESIOVA, L. - TIRPAKOVA, A. 2017. Zistovanie urovne vnimanej zdatnosti ucitelov vyssieho sekundarneho vzdelavania pomocou dotaznika OSTES. In Edukacia. Vedecko-odborny casopis, roc. 2, c. 1 , s. $160-174$.

TSCHANNEN-MORAN, M. - WOOLFOLK HOY, A. 2001. Teacher efficacy: Capturing an elusive construct. In Teaching and Teacher Education, vol. 17, p. $783-805$.

WOOLFOLK HOY, A. 2000. Changes in Teacher Efficacy During the Early Years of Teaching. Paper presented at annual meeting of American Educational Research Association, New Orleans.

Mgr. Katarína Kohútová, PhD.

Catholik University in Ruzomberok, Faculty of education

Hrabovská cesta 1,

Ružomberok, Slovakia

katarina.kohutova@ku.sk 